\title{
Gene regulation by the act of long non-coding RNA transcription
}

\author{
Aleksandra E Kornienko, Philipp M Guenzl, Denise P Barlow and Florian M Pauler*
}

\begin{abstract}
Long non-protein-coding RNAs (IncRNAs) are proposed to be the largest transcript class in the mouse and human transcriptomes. Two important questions are whether all IncRNAs are functional and how they could exert a function. Several IncRNAs have been shown to function through their product, but this is not the only possible mode of action. In this review we focus on a role for the process of IncRNA transcription, independent of the IncRNA product, in regulating protein-coding-gene activity in cis. We discuss examples where IncRNA transcription leads to gene silencing or activation, and describe strategies to determine if the IncRNA product or its transcription causes the regulatory effect.
\end{abstract}

Keywords: Gene expression regulation, Histone modifications, lincRNA, IncRNA, Silencing,

Transcriptional interference

\section{LncRNAs - a new layer of genome regulatory information}

It is now well appreciated that less than two percent of the human genome codes for proteins and the majority of the genome gives rise to non-protein-coding RNAs (ncRNAs) [1], which are predicted to play essential roles in a variety of biological processes [2,3].

The focus of this review is long ncRNAs (known as lncRNAs), which constitute the biggest class of ncRNAs with approximately 10,000 lncRNA genes so far annotated in humans [4]. IncRNAs are RNA polymerase II (RNAPII) transcripts that lack an open reading frame and are longer than 200 nucleotides. This size cut-off distinguishes lncRNAs from small RNAs such as microRNAs, piwi-interacting RNAs (piRNAs), small nucleolar RNAs (snoRNAs) and small interfering RNAs

\footnotetext{
* Correspondence: fpauler@cemm.oeaw.ac.at

CeMM Research Center for Molecular Medicine of the Austrian Academy of Sciences, Lazarettgasse 14, AKH-BT25.3, 1090, Vienna, Austria
}

(siRNAs) and arises from RNA preparation methods that capture RNA molecules above this size. Although the function of most lncRNAs is unknown, the number of characterized lncRNAs is growing and many publications suggest they play roles in negatively or positively regulating gene expression in development, differentiation and human disease [2,5-10]. IncRNAs may regulate protein-coding (pc) gene expression at both the posttranscriptional and transcriptional level. Posttranscriptional regulation could occur by lncRNAs acting as competing endogenous RNAs to regulate microRNA levels as well as by modulating mRNA stability and translation by homologous base pairing, or as in the example of NEAT1 that is involved in nuclear retention of mRNAs [11]. In this review we focus on the regulation at the transcriptional level.

\section{Modes of transcriptional regulation by IncRNAs}

Regulation of transcription is considered to be an interplay of tissue and developmental-specific transcription factors (TFs) and chromatin modifying factors acting on enhancer and promoter sequences to facilitate the assembly of the transcription machinery at gene promoters. With a growing number of lncRNAs implicated in transcriptional gene regulation, this view may need refinement to include networks of tissue and developmental-stage specific lncRNAs that complement known regulators to tightly control gene expression and thereby organism complexity $[12,13]$. Transcriptional regulation by lncRNAs could work either in cis or in trans, and could negatively or positively control pc gene expression. IncRNAs work in cis when their effects are restricted to the chromosome from which they are transcribed, and work in trans when they affect genes on other chromosomes.

\section{Regulation in trans}

Some significant examples of lncRNAs that act in trans are those that can influence the general transcriptional output of a cell by directly affecting RNAPII activity (Figure 1a,b). One example is the 331 nucleotide 7SK 
lncRNA, which represses transcription elongation by preventing the PTEF $\beta$ transcription factor from phosphorylating the RNAPII carboxy-terminal domain (CTD) [14] (Figure 1a). Another example is the $178 \mathrm{nu}$ cleotide B2 lncRNA, a general repressor of RNAPII activity upon heat shock [15]. The B2 lncRNA acts by binding RNAPII and inhibiting phosphorylation of its CTD by TFIIH, thus disturbing the ability of RNAPII to bind DNA $[16,17]$.
Regulation in trans can also act locus-specifically. While the ability of lncRNAs to act locus-specifically to regulate a set of genes was first demonstrated for imprinted genes where lncRNA expression was shown to silence from one to ten flanking genes in cis [18-20], lncRNAs that lie outside imprinted gene clusters, such as the HOTAIR lncRNA, were later found also to have locus-specific action. HOTAIR is expressed from the HOXC cluster and was shown to repress transcription in trans across $40 \mathrm{~kb}$

\section{Regulation in trans}

(a) TF inactivation

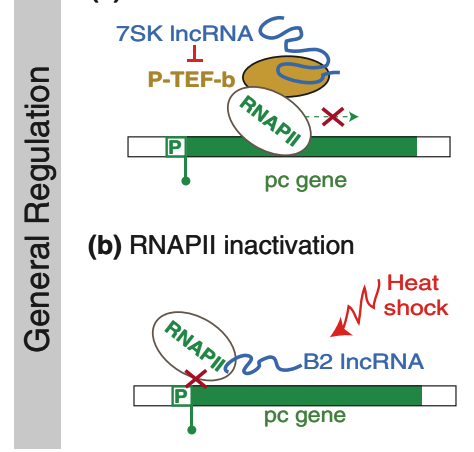

(d) Regulation by IncRNA product

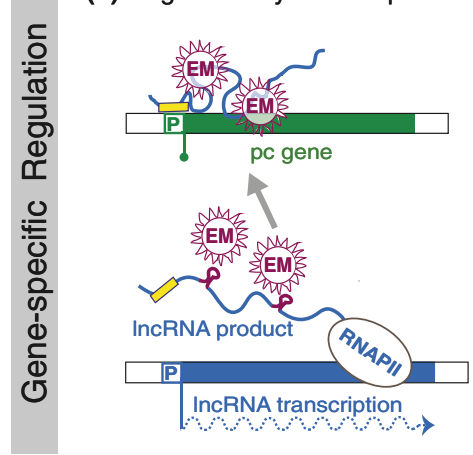

\section{Regulation in cis}

(c) $\mathrm{X}$ chromosome inactivation

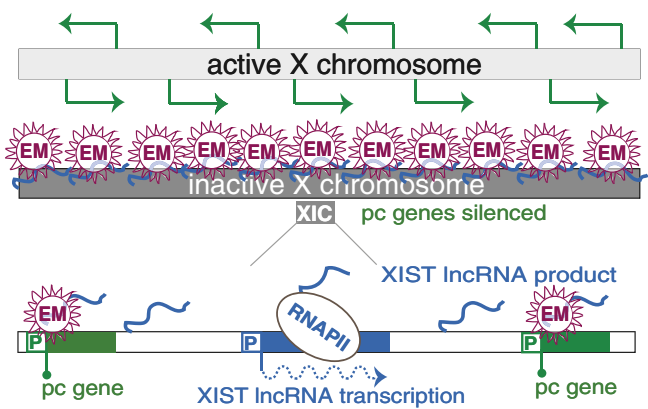

(e) Regulation by IncRNA product

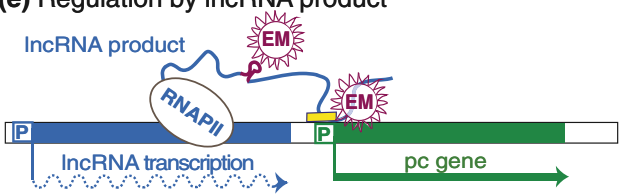

(f) Regulation by IncRNA transcription

IncRNA transcription

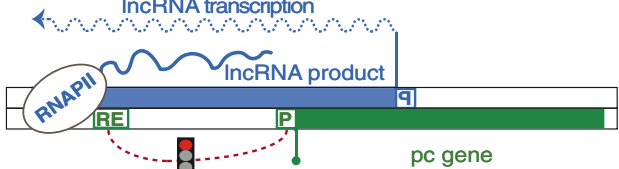

\section{G. Key}
P Protein-coding gene promoter $\quad\left[\begin{array}{ll}\text { P } \\ \text { forward strand }\end{array}\right.$ P LncRNA promoter
1 LncRNA transcription i Repressed functional transcription of a protein coding gene

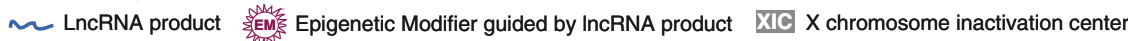
$\&$ LncRNA EM binding site (sequence/structure) $\quad$ RNA/DNA interaction element
$\longrightarrow$ Upregulated transcription of protein-coding gene RE Cis-regulatory element (enhancer, insulator)
- 8 . Disrupted cis-regulatory element-promoter interaction

Figure 1. Long non-protein-coding RNAs (IncRNAs) act at different levels to regulate protein coding gene expression. IncRNAs can inhibit general protein-coding (pc) gene expression in trans (a) by preventing transcription factor (TF) activity (7SK IncRNA) or (b) by inhibiting RNAPII binding to DNA (B2 IncRNA). Xist IncRNA is transcribed from the X inactivation center (XIC) and inactivates a whole chromosome in cis (c) by recruiting epigenetic modifiers (EM). IncRNAs can regulate specific genes, acting in trans like HOTAIR (d) or in cis like HOTTIP (e) by directly recruiting epigenetic modifiers to certain genomic loci. In both cases the IncRNA binds EMs via a specific sequence or structure and targets them to promoter regions via DNA/RNA interaction elements to affect expression of the respective pc gene. Transcription of a IncRNA through a pc gene promoter or a cis-regulatory element (RE) affects pc gene expression in cis independent of the IncRNA product (f) by mechanisms discussed in the text. Both DNA strands are shown as separate boxes to indicate IncRNA transcription over the pc gene promoter in the antisense orientation. For details see text. 
of the HOXD cluster [21]. HOTAIR interacts with Polycomb repressive complex 2 (PRC2) and is required for repressive histone $\mathrm{H} 3$ lysine-27 trimethylation (H3K27me3) of the HOXD cluster. Targeting of epigenetic modifiers (EMs) by lncRNAs provided a much sought after model to explain how EMs gain locus specificity (Figure 1d), and has since been suggested as a general mechanism for trans-acting lncRNAs [22,23].

\section{Regulation in cis}

In contrast to trans-acting lncRNAs, which act via their RNA product, cis-acting IncRNAs have the possibility to act in two fundamentally different modes. The first mode depends on a lncRNA product. The major example of general cis-regulation is induction of $\mathrm{X}$ inactivation by the Xist lncRNA in female mammals. Xist is expressed from one of the two $\mathrm{X}$ chromosomes and induces silencing of the whole chromosome [24] (Figure 1c). As an example of locus-specific regulation it has been proposed that enhancer RNAs activate corresponding genes in cis via their product [25]. A well-studied cis-acting lncRNA acting through its product is the human HOTTIP IncRNA that is expressed in the HOXA cluster and activates transcription of flanking genes. HOTTIP was shown to act by binding WDR5 in the MLL histone modifier complex, thereby bringing histone $\mathrm{H} 3$ lysine-4 trimethylation (H3K4me3) to promoters of the flanking genes [26]. Such a mechanism in which a nascent lncRNA transcript binds and delivers epigenetic modifiers to its target genes while still attached to the elongating RNAPII is generally termed 'tethering' and is often used to explain cis-regulation by lncRNAs [23,27] (Figure 1e). It was also proposed to act in plants. In Arabidopsis thaliana, the COLDAIR lncRNA is initiated from an intron of the FLC pc gene and silences it by targeting repressive chromatin marks to the locus to control flowering time [28].

In contrast, the second mode of cis regulation by lncRNAs involves the process of transcription itself, which is a priori cis-acting (Figure 1f). Several lines of evidence suggest that the mere process of lncRNA transcription can affect gene expression if RNAPII traverses a regulatory element or changes general chromatin organization of the locus. In this review we discuss this underestimated role for IncRNA transcription in inducing protein-coding gene silencing or activation in cis, and overview possible mechanisms for this action in mammalian and non-mammalian organisms. Finally, we describe experimental strategies to distinguish lncRNAs acting as a transcript from those acting through transcription.

\section{Mechanisms by which IncRNA transcription silences gene expression}

Transcription-mediated silencing, also referred to as 'transcriptional interference' (TI), is defined here as a case in which the act of transcription of one gene can repress in cis the functional transcription of another gene $[29,30]$. TI has been reported in unicellular and multicellular organisms [30]. Mechanistic details are still largely unclear, but TI could theoretically act at several stages in transcription: by influencing enhancer or promoter activity or by blocking RNAPII elongation, splicing or polyadenylation. All that would be required is that the RNA polymerase (RNAPII) initiated from an 'interfering' promoter traverses a 'sensitive' DNA regulatory sequence. TI has mainly been reported at overlapped promoters [31-35], but there are also examples where TI acts downstream of the promoter. In mouse, overlapping transcription controls polyadenylation choice of two imprinted genes [36,37]. In Saccharomyces cerevisiae, collisions between elongating antisense RNAPIIs can lead to stalling of both polymerases that is resolved by ubiquitylation-directed proteolysis, and this has been proposed to be a regulatory mechanism [38]. However, it is unknown if RNAPII collisions occur sufficiently frequently in vivo in yeast or other organisms to offer a means of regulating convergent genes, or if this mechanism could lead to an interfering RNAPII eliminating its sensitive collision partner. Despite these examples, the most common reports of TI concern an overlapped promoter, and in the following sections we describe studies investigating the molecular mechanisms underlying interference at the promoter.

\section{Transcriptional interference acting by promoter nucleosome repositioning}

DNA in the nucleus is organized into chromatin with the organizational scaffold consisting of nucleosomes, each with two copies of H3, H4, H2A and H2B histones [39]. Nucleosomes can be densely packed, interfering with protein-DNA interactions, or relaxed, facilitating these interactions [40]. The transcription process, which generates single-stranded DNA as RNAPII progresses along a gene locus, can directly affect nucleosome positioning [41-43] (reviewed in [44,45]). Thus, lncRNA transcription could cause TI by depositing nucleosomes in a manner unfavorable for TF binding on promoters or enhancers. An example of this mechanism is the silencing of the yeast SER3 pc gene by transcriptional overlap by the SRG1 lncRNA (Figure 2a) [46]. SRG1 transcription increases nucleosome density at the overlapped SER3 promoter. Deletion of three transcription elongation factors that are associated with the elongating polymerase and are necessary for nucleosome repositioning (SPT16, SPT6, SPT2) [47-49] abolished the silencing effect without stopping transcription of the overlapping lncRNA SRG1 [50,51], indicating the necessity of chromatin reorganization for silencing. In contrast, deletion of epigenetic modifiers (such as SET1/2 
(a) LncRNA transcription causes increased nucleosome density (yeast)

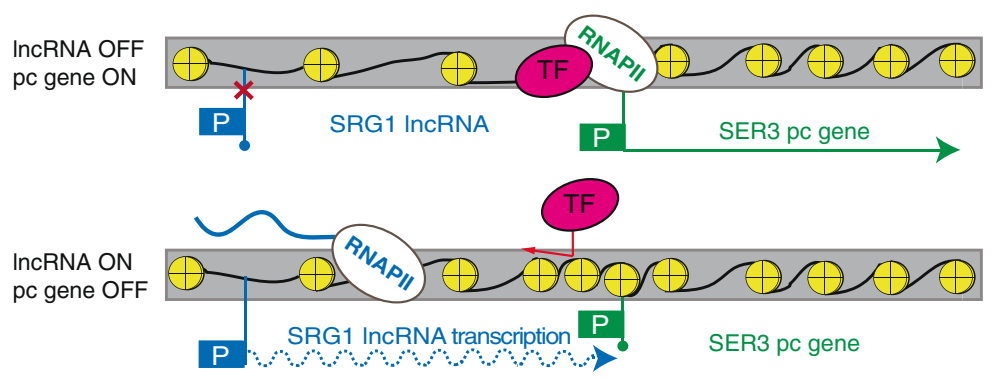

(b) LncRNA transcription causes repressive hisone modifications (yeast)

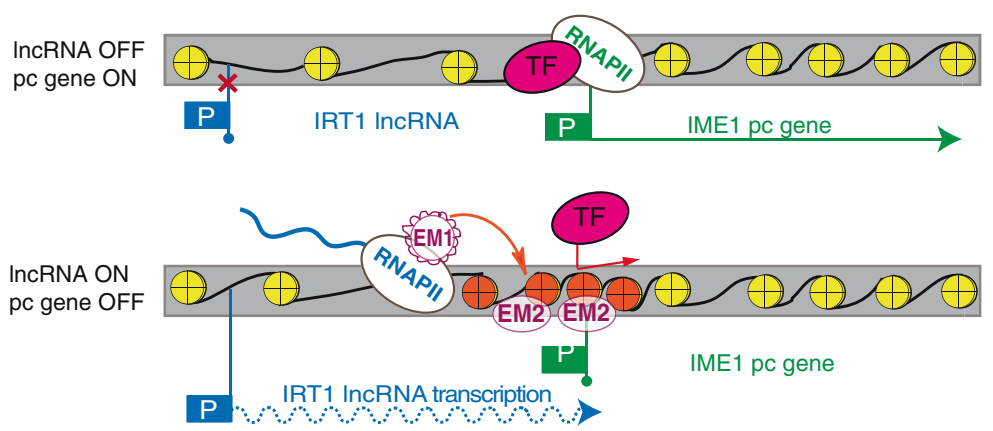

(c) Aberrant transcription recruits DNA methylation to overlapped promoter (human)

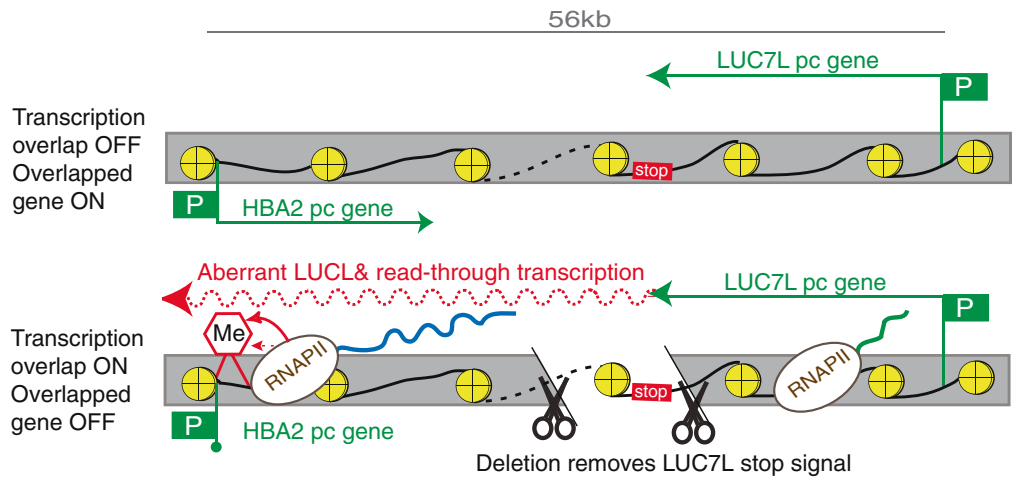

(d) Key

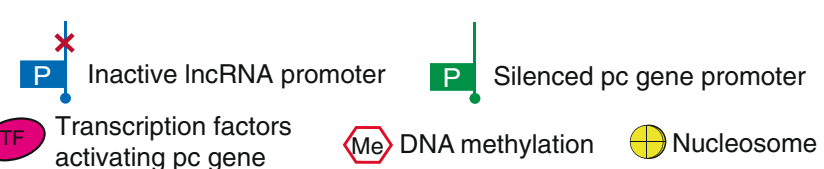

Nucleosome with repressive histone modifications

Epigenetic modifiers travel with RNAPII and deposit H3K4me2 and H3K36me3

(EM2) Epigenetic modifiers performing deacetylation

Figure 2. Transcription interference-mediated silencing by chromatin changes. (a) Top: in yeast the absence of SRG1 IncRNA allows transcription machinery assembly at the SER3 protein coding gene promoter. Bottom: SRG1 IncRNA transcription causes dense nucleosome packing over the downstream SER3 PC gene promoter that blocks TF binding and pc gene expression. (b) Top: in yeast the absence of IRT1 IncRNA allows IME1 pc gene expression. Bottom: RNAPII transcribing the IRT1 IncRNA carries EMs that deposit repressive histone modifications at the IME1 promoter (EM1 - methyltransferases). These modifications allow the binding of other EMs that remove active histone modifications (EM2 deacetylases) and cause a repressive chromatin environment that blocks TF binding leading to silencing. (c) Top: in a healthy human, LUC7L and HBA2 pc genes do not overlap and are both expressed. Bottom: a chromosomal deletion of the LUC7L transcriptional stop signal (red 'stop' box) causes transcription of the LUC7L pc gene through the promoter of the HBA2 pc gene. By an unknown mechanism this aberrant transcription causes DNA methylation and silencing of the HBA2 promoter. For details see Figure $1 \mathrm{~g}$ and text. 
histone methyltransferases and SET3C/RPD3S deacetylases described later) did not affect silencing, showing that nucleosome positioning, but not changes in histone modifications, is responsible for repression. The experiments did not directly exclude a role for the $S R G 1$ lncRNA product, but the silencing can be explained solely by the process of transcription $[44,45]$. TI by nucleosome repositioning may be a general mechanism in yeast, as the RNAPII elongation and chromatin organization factors responsible for SER3 silencing are also known to be involved in the suppression of transcription initiation from cryptic promoters within the body of actively transcribed genes [52,53]. Since genes controlling RNAPII elongation and chromatin organization are largely conserved, it is possible that lncRNAs could use similar nucleosome repositioning silencing in mammals. This is supported by the example that chromatin reassembly factors are necessary for silencing an HIV provirus when integrated into an actively transcribed host gene in a human cell system [54].

\section{Transcriptional interference acting by promoter histone modifications}

Promoter associated nucleosomes carry post-translational histone tail modifications that reflect the activity state of the promoter and also influence accessibility of DNA binding factors involved in transcription [55]. Active gene promoters correlate with $\mathrm{H} 3$ and $\mathrm{H} 4$ acetylation and with H3K4me3, while inactive promoters do not and, in mammals, they also gain repressive histone marks such as H3K9me3 or H3K27me3. Some histone modifying enzymes have been shown to bind and travel with elongating RNAPII [56,57], so it is possible that lncRNA transcription can induce TI by affecting histone modifications at the promoter of an overlapped target gene. For example, in yeast the SET1/2 methyltransferases, which induce H3K4me2 and H3K36me3 in the body of transcribed genes, bind and travel with elongating RNAPII [58-60]. These modifications in turn recruit the SET3C/RPD3S histone deacetylase complexes to create a chromatin environment repressive for transcription initiation [61-63].

Two studies indicate that this is a mechanism used by lncRNAs to induce TI in yeast. In the first study the $I M E 1$ pc gene, which induces gametogenesis in diploid S. cerevisiae cells but is repressed in haploid cells, was shown to be silenced by the IRT1 IncRNA that overlaps its promoter [64]. Genetic experiments repositioning the IRT1 lncRNA distant from IME1 on the same chromosome showed that IRT1 transcriptional overlap of the $I M E 1$ promoter is necessary for silencing. Interestingly, the instability of the IRT1 lncRNA product and its nonspecific cellular localization indicated the lncRNA product is unlikely to play a role in the silencing mechanism. Instead, IRT1 lncRNA transcription through the IME1 promoter reduced recruitment of the essential POG1 transcription factor, increased nucleosome density and induced the SET1/2 mediated cascades of histone modifications, which were shown to be necessary for silencing [64] (Figure 2b). In the second study lncRNA transcription was shown to be causative for silencing of the GAL1 and GAL10 genes, involved in galactose metabolism in S. cerevisiae. GAL10 and GAL1 are divergently transcribed from a bidirectional promoter. The $4 \mathrm{~kb}$ lncRNA, called GAL10-ncRNA, initiates in the body of the GAL1O gene, and is transcribed through the GAL10/GAL1 promoter antisense to the GAL10 gene. GAL10-ncRNA transcription induces SET2-mediated establishment of H3K36me3 along its gene body, thereby recruiting RPD3Sdependent deacetylation that resulted in reduced transcription factor binding and repression of the GAL1/GAL10 promoter [65]. Both SET3C and RPD3S are proposed to have a general role in repressing cryptic promoters within gene bodies $[61,66]$ and a genome-wide study implied a role for SET3C in overlapping lncRNA-mediated silencing of a set of pc genes in yeast [66]. This indicates that the mechanism described above might be widely used to control gene expression in yeast. Although similar studies have not been described for the mammalian genome, H3K36me3 marks the body of transcribed genes in mammals, raising the possibility that such TI mechanisms could be conserved [56,57].

\section{Transcriptional interference acting by promoter DNA methylation}

In mammalian genomes DNA methylation is generally associated with silent $\mathrm{CpG}$ island promoters, but the majority of CpG island promoters remain methylation free independent of their expression status [67-69]. The process of de novo methylation depends on the DNMT3A/3B methyltransferases and the catalytically inactive DNMT3L homologue and requires histones lacking H3K4me3, ensuring that active promoters remain methylation-free [70]. Notably, while DNA methylation at the promoter blocks transcription initiation, methylation in the gene body does not. Two important examples in humans based on genetic analyses indicate that DNA methylation can be involved in TI-induced silencing, although the causality between DNA methylation and silencing is still a matter of discussion [67]. One study of a patient with inherited $\alpha$-thalassemia identified a deletion of the $L U C 7 L 3^{\prime}$ end that allowed aberrant transcription of $L U C 7 L$ through the downstream $H B A 2$ gene, causing its silencing and the disease phenotype [71] (Figure 2c). Mouse models that mimicked the deleted genomic locus showed that the main cause of silencing was the acquisition of DNA methylation at the $H B A 2$ promoter. Notably, DNA methylation acquisition was not simply the consequence of an inactive promoter, as removal of $H B A 2$ transcription by deleting its TATA box did not induce methylation. The sequence of the 
LUC7L gene and thus the aberrant RNA product was also not essential for HBA2 silencing, as replacing the $L U C 7 L$ gene body with another protein-coding gene did not remove the repressive effect. In a second example, a subset of Lynch syndrome patients display DNA methylation and inactivation of the mismatch repair $\mathrm{MSH} 2$ gene that correlates with aberrant transcription from the flanking EPCAM gene that carries a 3' deletion [72].

In both these examples, the molecular details of methylation establishment and the mechanism by which the methylation machinery targets the overlapped promoter are yet unknown. However, the data so far show that it is a cis-acting mechanism as only the allele carrying the deletion silences the overlapped protein-coding gene. In addition, although a role for the aberrant RNA product was not excluded, it appears unlikely that mutation-induced transcription of two independent intergenic chromosomal regions in the described diseases produces lncRNA products with similar repressive functions. Interestingly, the silencing of imprinted pc genes by lncRNAs is also often correlated with the gain of DNA methylation on the silent pc gene promoter [73]. In the case of the Igf2r gene, this DNA methylation mark is not necessary for initiation or maintenance of the silent state but seems to play a role in re-enforcing the silent state $[35,74]$.

\section{Transcriptional interference in the absence of chromatin changes at the silenced promoter}

In addition to RNAPII acting as a carrier of chromatin modifying enzymes, other TI models predict that RNAPII from one promoter traversing across another promoter can interfere with its activity without introducing chromatin changes $[30,75,76]$. An indication that such a mechanism can be used by lncRNAs in mammals comes from a study that used a genetic approach to dissect the silencing function of the imprinted mouse Airn lncRNA [77,78]. Airn is an inefficiently spliced $118 \mathrm{~kb}$ lncRNA expressed on paternally inherited chromosomes that overlaps and silences the promoter of the Igf $2 r$ pc gene - a dose-sensitive and essential embryonic growth suppressor [18,79] (Figure 3a). To determine if Airn transcription or its lncRNA product were required for silencing, homologous recombination in embryonic stem cells was used to shorten the length of Airn, either before or after the $I g f 2 r$ promoter, by insertion of a polyadenylation cassette [35]. Notably, only shortened Airn variants that traversed the $I g f 2 r$ promoter induced silencing. Furthermore, while $\operatorname{Ig} 22 r$ silencing is normally accompanied by DNA methylation, repressive histone marks and chromatin compaction of the silent Igf2r promoter [80,81], Igf $2 r$ silencing was not dependent on DNA methylation - in contrast to the silencing of $H B A 2$ by aberrant $L U C 7 L$ transcription described above.
Instead, Airn transcriptional overlap interfered with the accumulation of functional RNAPII on the Igf $2 r$ promoter in the presence of open chromatin [35]. Additional support for Igf $2 r$ silencing by Airn transcriptional interference is provided by genetic experiments that used an inducible Airn promoter to silence $I g f 2 r$ at different stages of embryonic stem cell differentiation [74]. The demonstration that Airn transcription is continuously required for $I g f 2 r$ silencing and that its silencing efficiency decreases when the $I g f 2 r$ promoter is strongly expressed provides support for a model whereby RNAPII initiated from an 'interfering' promoter interferes with transcription initiation from a 'sensitive' promoter.

To date, other examples of lncRNAs acting by this mechanism in mammals are lacking. It has been suggested that silencing of an alternative promoter of the mouse fpgs pc gene is an example of transcription inducing silencing without introducing chromatin changes [82], but this system has not been subject to a similar genetic analysis and alternative explanations remain possible. How RNAPII from an interfering promoter is able to suppress functional transcription of the overlapped promoter remains to be determined, but stalling of the interfering RNAPII elongating over the sensitive promoter has been suggested to block access of essential TFs [30,83]. This mechanism should not be confused with the phenomenon of genome-wide RNAPII pausing at promoters, which represents an intermediate step between RNAPII initiation and elongation phases and might be a common mechanism regulating differential gene expression in metazoans $[84,85]$.

The above examples describe repressive effects from RNAPII transcribing lncRNAs through promoters of silenced genes. However, transcriptional interference might also disrupt enhancer function when RNAPII traverses an enhancer, and this is an attractive model to explain the repression of a cluster of genes by a lncRNA in a tissue-specific manner [75] (Figure 3b). This situation arises in two imprinted gene clusters where the Airn and Kcnq1ot1 lncRNAs each overlap one gene, but silence multiple genes in cis in a tissue-specific manner. The repressive histone EHMT2 methyltransferase has been shown to be necessary in the placenta to silence one of the three genes controlled by Airn [86]. The Kcnq1ot1 lncRNA has been shown to silence multiple genes in placental cells by the action of repressive POLYCOMB histone modifying enzymes $[87,88]$. In both cases, a direct role for the lncRNA in targeting the histone modifying complexes was proposed, based on the findings that the lncRNAs interact with the respective histone modifying complex. This correlation-based evidence is, however, not sufficient to rule out the possibility that both lncRNAs silence distant genes by transcription alone (reviewed in $[75,76]$ ). In support of a transcription-based 
(a) Airn IncRNA transcriptional interference silences the paternal Igf2r promoter

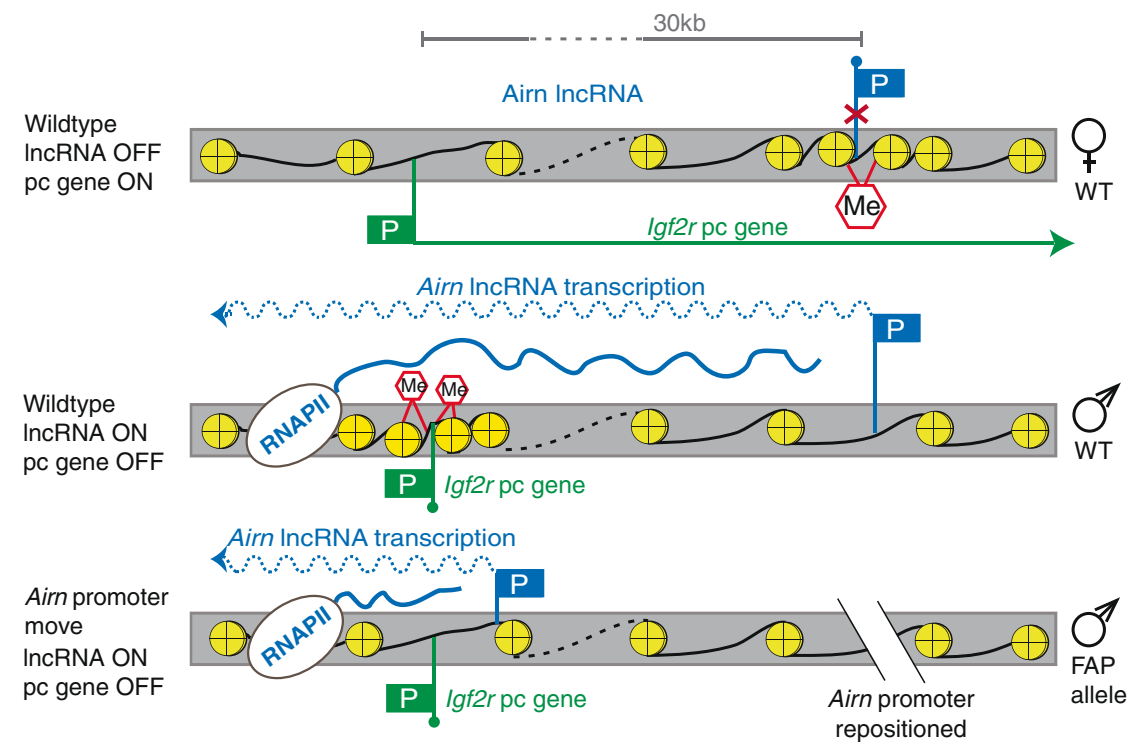

(b) LncRNA transcription overlapping enhancer blocks mRNA expression

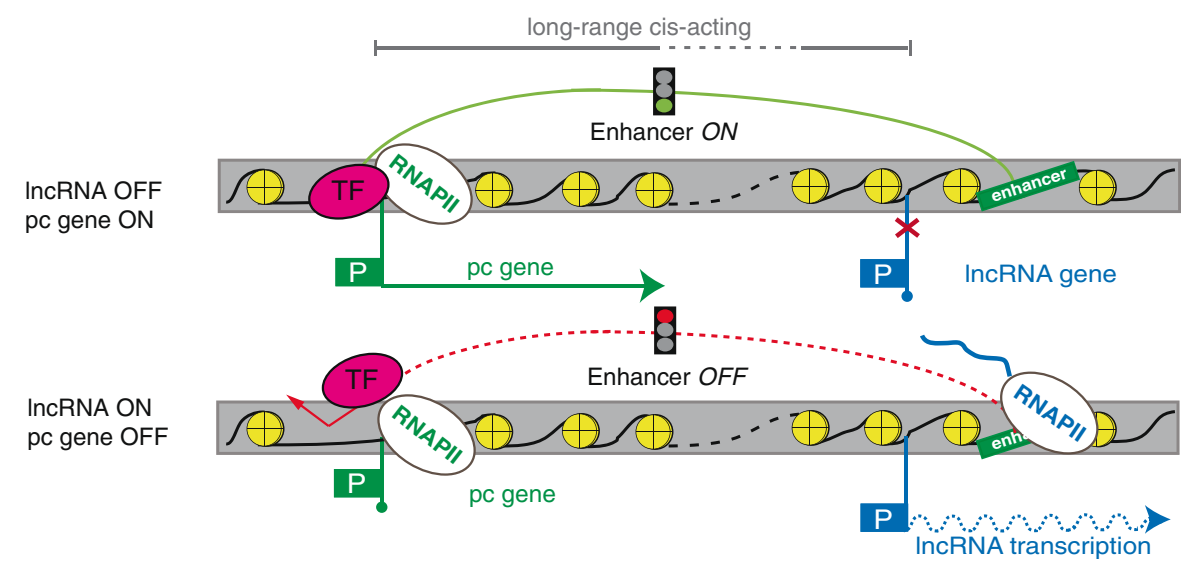

(c) Key

q Maternal allele $\bigcirc$ Paternal allele

Figure 3. Transcription interference-mediated silencing without chromatin changes. (a) Top: a wild-type maternal allele does not express Airn IncRNA as its promoter is repressed by a DNA methylation imprint, thus allowing the lgf2r gene to be active. Middle: on the wild-type paternal allele Airn transcription overlaps with and silences the Igf2r pc gene promoter, independent of the Airn IncRNA product. The silent Igf2r promoter is marked by increased nucleosome density and DNA methylation in the absence of active histone modifications. Bottom: increased nucleosome density, loss of active histone marks and DNA methylation are not necessary for lgf2r repression as demonstrated by the FAP allele that moved the Airn promoter close to the Igf2r promoter and silenced Igf2r in the absence of repressive chromatin features. (b) Top: a hypothetical enhancer activates a pc gene by direct long-range DNA interactions. Bottom: transcription of a IncRNA overlapping the enhancer interferes with the DNA interaction and thereby silences the $p c$ gene. For details see Figure $1 \mathrm{~g}$, Figure $2 \mathrm{~d}$ and text.

model, it was shown that Kcnq1ot1 silences at least one gene by regulating chromatin flexibility and access to enhancers [89]. This is consistent with a two-step model whereby lncRNA transcription initiates silencing of nonoverlapped genes by enhancer interference, then repressive histone modifying enzymes maintain that silencing.

\section{IncRNA transcription creating a permissive chromatin environment}

Enhancers are genetic elements that bind transcription factors facilitating transcription machinery assembly at nearby promoters $[90,91]$. RNAPII transcripts up to $2 \mathrm{~kb}$ long are transcribed bi-directionally from some neuronal 
enhancers (termed enhancer or eRNAs) [91,92]. Transcription of eRNAs positively correlated with expression of nearby mRNAs and a model was proposed, but not yet experimentally tested, in which their transcription establishes a chromatin landscape that supports enhancer function (Figure 4a). lncRNA transcription, either by opening chromatin or inhibiting repressor protein binding, could similarly result in gene or locus activation. One example of this is the process of $\mathrm{V}(\mathrm{D}) \mathrm{J}$ recombination, which joins elements of the $\mathrm{V}, \mathrm{D}$ and $\mathrm{J}$ multigene family by chromosomal rearrangements to create functional B cell immunoglobulins and T cell receptors [93] (Figure $4 \mathrm{~b}$ ). The V, D and J genes lie next to each other on the same chromosome and antisense intergenic transcription through these genes is detected prior to the recombination process [94]. Genetic experiments have shown that intergenic lncRNA transcription is required for both B and T cell V(D)J recombination [95,96]. Similar correlations between intergenic transcription and gene expression were observed for the mouse $\beta$-globin locus [97] where promoter deletion experiments showed that lncRNA transcription was responsible for stable, active and hyper-accessible chromatin [98].

\section{IncRNA transcription and locus activation}

Other examples indicate that lncRNA transcription activates gene expression by blocking access of repressor complexes to chromatin. In Drosophila, intergenic noncoding transcription at the BITHORAX complex $(B X-C)$ is implicated in reversing $P O L Y C O M B$ group (PCG)-mediated gene silencing and is correlated with an active chromatin state [99]. This mode of action was later suggested to be a general mechanism where the act of transcription serves as an epigenetic switch that relieves PCG-mediated gene silencing by recruiting epigenetic modifiers to induce gene expression and generate stable and heritable active chromatin [100]. In line with this hypothesis, intergenic transcription through PCG response elements (PREs) in the $B X-C$ cluster is not only found during embryogenesis but also in late stage larvae, indicating that continuous transcription is required to keep genes active [101]. In mouse and human, a similar role for PRE transcription has been proposed. An analysis of lncRNA transcription in the human HOXA cluster revealed a positive correlation between IncRNA transcription and the loss of PCG/chromatin interactions that precedes HOXA gene activation [102]. Additionally, IncRNAs have been identified at promoter regions of PCG-regulated genes in mouse cells; while their role is not yet clear, it has been suggested that they either promote or interfere with PCG binding at target genes [103,104].

A further example of a lncRNA mediating chromatin opening was described at the S. cerevisiae PHO5 gene. Transcription of an antisense lncRNA that initiates near the 3'end of $\mathrm{PHO} 5$ and overlaps its gene body and promoter is associated with rapid activation of $\mathrm{PHOS}$ by enabling nucleosome eviction. Biochemical inhibition of RNAPII elongation as well as genetic disruption of lncRNA elongation demonstrated a direct role in $\mathrm{PHO5}$ activation [105]. The association of lncRNA transcription with gene activation needs, however, to be considered within the framework that most protein-coding gene promoters in yeast and mammalian cells give rise to a bidirectional antisense lncRNA transcript $[106,107]$. To date it is unclear if promoter-associated bidirectional lncRNAs represent spurious transcription in the context of open chromatin $[108,109]$ or is required to maintain open chromatin. In the latter case enhanced TF binding ensures accessible chromatin that allows more constant pc gene expression within a cell population [110] (Figure 4c).

\section{Strategies for distinguishing a role for the IncRNA product from that of its transcription}

Following genome-wide lncRNA mapping, functional studies so far have mainly focused on lncRNA products $[7,111]$. As it becomes clear that lncRNAs can act through their transcription, it is important to identify strategies to determine the function and mode of action of each particular lncRNA. One common starting point to determine lncRNA function has been RNA interference (RNAi)-mediated knockdown, despite long-standing observations that the RNAi machinery in mammalian cells is located in the cytoplasm [112]. While there is evidence that some RNA-induced silencing complex (RISC) components are found in the nucleus, functional complexes are specifically loaded in the cytoplasm, prohibiting the application of RNAi strategies for nuclear localized lncRNAs [113]. In contrast, antisense oligonucleotides (ASO) that work via an RNaseH-dependent pathway will deplete nuclearlocalized lncRNAs $[114,115]$. However, three additional points of caution should be noted. First, non-specific effects arising from nuclear transfection reagents [116] have confused some observations. One critical validation step for knockdown studies would be a rescue experiment in which the IncRNA, modified to be invulnerable to the knockdown, is expressed as a transgene under the same transfection conditions [111]. Second, some results have highlighted major differences when functional studies used post-transcriptional depletion strategies in cell lines in contrast to genetic studies in the organism. Notable examples are Neat1 [117], Malat1 [116,118,119] and Hotair [120] where studies of mice carrying genetically disrupted alleles of these three lncRNAs failed to reproduce phenotypes deduced from cell lines following RNAi, ASO or over-expression studies. Third, while knockdown experiments may elucidate the function of lncRNAs acting through their product, the function of cis-acting lncRNAs that depend only on transcription will not be disturbed. 
(a) LncRNA transcription allows enhancer activity

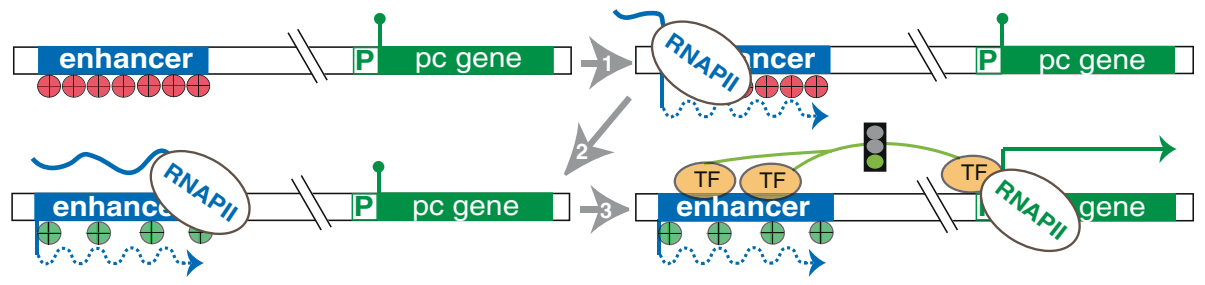

(b) LncRNA transcription allows VDJ recombination

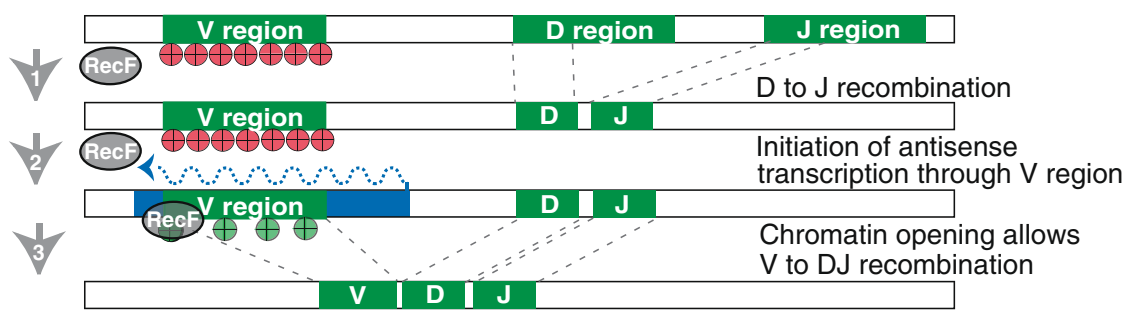

(c) Expression control at bidirectional promoters

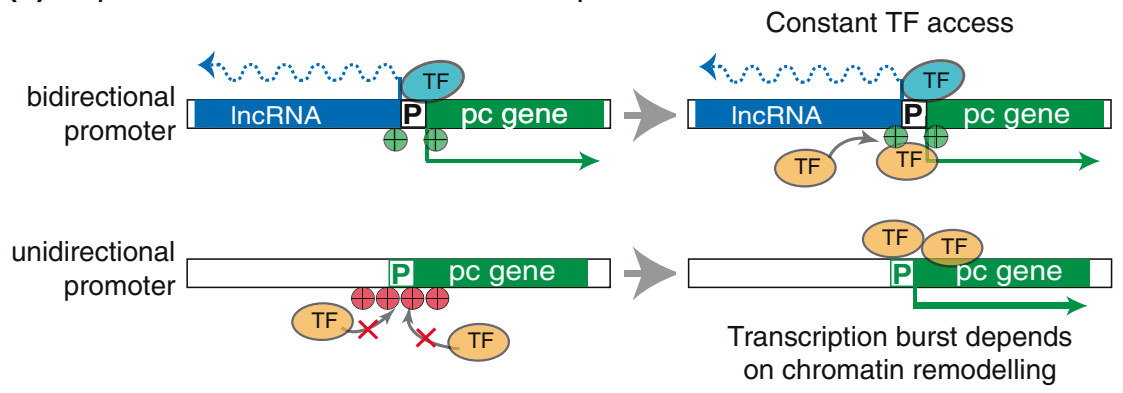

(d) Key
$\oplus \oplus$ Open chromatin $\oplus \oplus \oplus$ Closed chromatin RecF Recombination factor

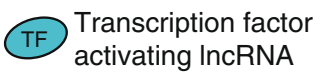
Transcription factor

Figure 4. Transcription of IncRNA creates permissive chromatin environment. (a) Top left: an inactive enhancer with closed chromatin cannot activate the pc gene. Top right, bottom left: transcription of the enhancer opens chromatin. Bottom right: open chromatin at the enhancer allows TF binding and interaction with and activation of the pc gene promoter. (b) VDJ recombination. From top to bottom: 1, D and J segments are joined and the $V$ region has closed chromatin; 2, antisense transcription through the $V$ region opens the chromatin and allows recombination factors to bind; 3, a V segment is joined to the DJ segment. (c) Top: at a bidirectional promoter a IncRNA and a pc gene are transcribed in opposite directions. The promoter is always in an open chromatin conformation as either the IncRNA or the pc gene is transcribed, which is thought to reduce transcriptional noise. Bottom: a unidirectional pc gene promoter can acquire a closed chromatin conformation due to stochastic TF binding, which is thought to increase transcriptional noise. Noise defines the variation of expression of a transcript between genetically identical cells caused by the stochastic binding of TFs regulated by the local chromatin environment. For details see Figure $1 \mathrm{~g}$, Figure $2 \mathrm{~d}$, Figure $3 \mathrm{c}$ and text.

Features such as subcellular localization, half-life and steady-state abundance would form a good basis to allow functional tests to be designed. In addition, knowledge of the lncRNA splicing efficiency, conservation of splicing pattern in multiple tissues and species, an estimation of transcript repeat content and, finally, an accurate mapping of lncRNA 5' and 3' ends are essential preliminary steps. We have previously proposed that a subclass of lncRNAs, 'macro' lncRNAs, show RNA biology hallmarks such as inefficient splicing, extreme length, high repeat content, lack of conservation and a short half-life. These features are also indicators that the lncRNA product is less important than the act of transcription [121]. Once RNA biology features are known, experiments can be designed to distinguish between a role for the lncRNA product or its transcription.

From the caveats of posttranscriptional knockdown experiments described above, it becomes clear that genetic 


\section{Cis-regulation by IncRNA product Cis-regulation by IncRNA transcription}

(a) LncRNA expression correlates with mRNA silencing
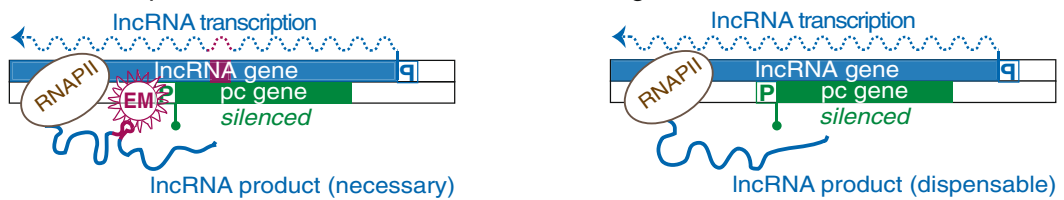

(b) LncRNA product knockdown
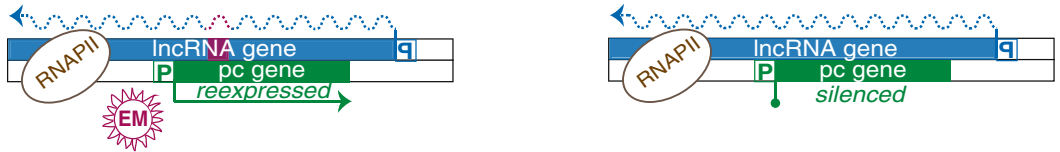

(c) LncRNA promoter deletion
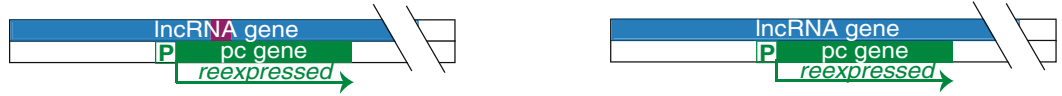

(d) LncRNA truncations
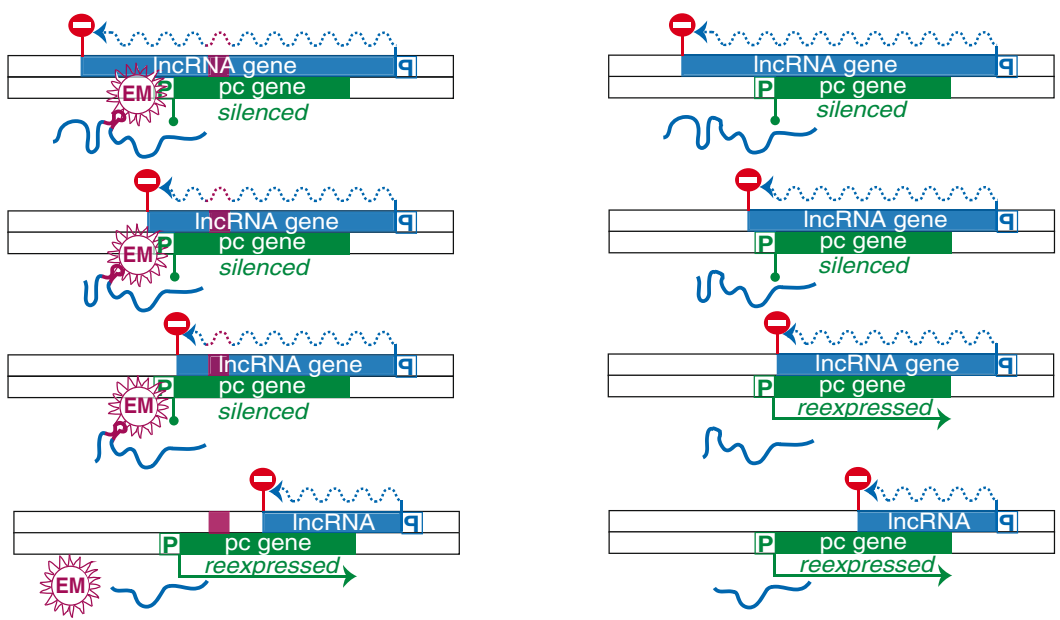

(e) Key

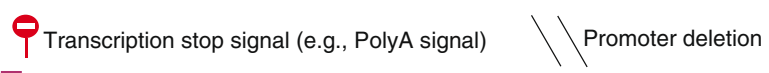

Region of the IncRNA gene corresponding to the IncRNA EM binding site

Figure 5. Strategies to distinguish between the function of a IncRNA product and its transcription. Both DNA strands are shown as separate boxes to indicate a IncRNA transcribed from the top reverse strand, overlapping a pc gene transcribed from the bottom forward strand in antisense orientation. A silencing function of the IncRNA can be predicted by an anti-correlating expression pattern. (a) Left: the IncRNA silencing effect is mediated by tethering of the IncRNA product at the site of transcription, sequence-specific binding of an EM to the IncRNA and guidance of the EM to the pc gene promoter. Right: silencing is mediated by a transcription process independent of the IncRNA product. (b) Posttranscriptional knockdown removes the IncRNA product, thus reversing a IncRNA product-mediated effect (left) but not the transcriptionmediated effect (right). (c) IncRNA promoter deletion removes both IncRNA product- (left) and transcription-mediated (right) effects. (d) Truncation experiments inserting transcriptional stop signals at different positions within the IncRNA gene identify the functional region of the IncRNA gene (RNAPII is not shown). Left: IncRNA is only functional when the region corresponding to EM binding site is present. Right: IncRNA is only functional when it crosses the promoter of the overlapped pc gene. For details see Figure $1 \mathrm{~g}$, Figure 2e, Figure $3 \mathrm{c}$, Figure $4 \mathrm{~d}$ and text.

strategies are optimal for testing lncRNA function. These strategies include manipulating the endogenous locus to delete the promoter or the whole gene or to shorten its length using inserted polyadenylation signals, as described for several examples above. This may appear a formidable task with the appreciation that lncRNAs in the human genome may outnumber protein-coding genes [4]; however, suitable cell systems already exist. These include the use of haploid cell lines with transcriptional stop signal insertions in most human genes that are screened by RNA sequencing [122], gene targeting by engineered zinc-finger nucleases [123] or CRISPR systems [124] or the use of mouse embryonic stem cells that have efficient rates of homologous targeting $[125,126]$. 
These genetic strategies could be applied to determine if the lncRNA is functional and if its function requires the IncRNA product or only depends on the act of transcription (Figure 5). Once these answers are obtained, it will be useful to test whether additional chromatin features are involved. This could include chromatin accessibility assays to address nucleosome density in the regulated gene; and mapping of histone modifications and DNA methylation, and of the presence of RNAPII and other transcription machinery components. These studies have been made easier in the mouse and human genome due to the publicly available ENCODE data [127]. As IncRNA identification becomes easier due to improved sequencing and bioinformatics tools, the number of annotated lncRNA transcripts is rising sharply $[4,128]$. It is therefore a high priority to determine which lncRNAs are functional and which represent spurious transcription $[109,129]$. To date only a relatively small number of mammalian lncRNAs have clearly been shown to regulate gene expression and most attention has centered on lncRNAs that act through their transcription product [23]. With the recent demonstration that for some mammalian lncRNAs the act of their transcription is sufficient for function [35], it becomes clear that there can be a number of IncRNAs acting in a similar way. If the above described findings and approaches are used as guidelines, many new lncRNAs regulating genes by the act of transcription are likely to be discovered.

\section{Acknowledgements}

We thank Quanah Hudson and Federica Santoro for comments on the manuscript. The authors are partly supported by the Austrian Science Fund: FWF SFB-F43 and FWF W1207-BO9. PG is recipient of a DOC Fellowship of the Austrian Academy of Sciences.

Published: 30 May 2013

\section{References}

1. Djebali S, Davis CA, Merkel A, Dobin A, Lassmann T, Mortazavi A, Tanzer A, Lagarde J, Lin W, Schlesinger F, Xue C, Marinov GK, Khatun J, Williams BA, Zaleski C, Rozowsky J, Röder M, Kokocinski F, Abdelhamid RF, Alioto T, Antoshechkin I, Baer MT, Bar NS, Batut P, Bell K, Bell I, Chakrabortty S, Chen $X$, Chrast J, Curado J, et al: Landscape of transcription in human cells. Nature 2012, 489:101-108.

2. Wilusz JE, Sunwoo H, Spector DL: Long noncoding RNAs: functional surprises from the RNA world. Genes Dev 2009, 23:1494-1504.

3. Pauli A, Rinn JL, Schier AF: Non-coding RNAs as regulators of embryogenesis. Nat Rev Genet 2011, 12:136-149.

4. Derrien T, Johnson R, Bussotti G, Tanzer A, Djebali S, Tilgner H, Guernec G, Martin D, Merkel A, Knowles DG, Lagarde J, Veeravalli L, Ruan X, Ruan Y, Lassmann T, Carninci P, Brown JB, Lipovich L, Gonzalez JM, Thomas M, Davis CA, Shiekhattar R, Gingeras TR, Hubbard TJ, Notredame C, Harrow J, Guigó $R$ : The GENCODE v7 catalog of human long noncoding RNAs: analysis of their gene structure, evolution, and expression. Genome Res 2012, 22:1775-1789.

5. Taft RJ, Pang KC, Mercer TR, Dinger M, Mattick JS: Non-coding RNAs: regulators of disease. J Pathol 2010, 220:126-139.

6. Huarte M, Rinn JL: Large non-coding RNAs: missing links in cancer? Hum Mol Genet 2010, 19:R152-R161.

7. Guttman M, Donaghey J, Carey BW, Garber M, Grenier JK, Munson G, Young G, Lucas AB, Ach R, Bruhn L, Yang X, Amit I, Meissner A, Regev A, Rinn JL,
Root DE: Lander ES: lincRNAs act in the circuitry controlling pluripotency and differentiation. Nature 2011, 477:295-300.

8. Gupta RA, Shah N, Wang KC, Kim J, Horlings HM, Wong DJ, Tsai MC, Hung T, Argani P, Rinn JL, Wang Y, Brzoska P, Kong B, Li R, West RB, van de Vijver MJ, Sukumar S, Chang HY: Long non-coding RNA HOTAIR reprograms chromatin state to promote cancer metastasis. Nature 2010, 464:1071-1076.

9. Prensner JR, lyer MK, Balbin OA, Dhanasekaran SM, Cao Q, Brenner JC, Laxman B, Asangani IA, Grasso CS, Kominsky HD, Cao X, Jing X, Wang X, Siddiqui J, Wei JT, Robinson D, lyer HK, Palanisamy N, Maher CA, Chinnaiyan AM: Transcriptome sequencing across a prostate cancer cohort identifies PCAT-1, an unannotated lincRNA implicated in disease progression. Nat Biotechnol 2011, 29:742-749.

10. Yap KL, Li S, Munoz-Cabello AM, Raguz S, Zeng L, Mujtaba S, Gil J, Walsh MJ, Zhou MM: Molecular interplay of the noncoding RNA ANRIL and methylated histone $\mathrm{H} 3$ lysine 27 by polycomb CBX7 in transcriptional silencing of INK4a. Mol Cell 2010, 38:662-674.

11. Yoon JH, Abdelmohsen $\mathrm{K}$, Gorospe M: Posttranscriptional gene regulation by long noncoding RNA. J Mol Biol 2012. pii:S0022-2836(12)00896-0.

12. Mattick JS: Deconstructing the dogma: a new view of the evolution and genetic programming of complex organisms. Ann N Y Acad Sci 2009 1178:29-46.

13. Mattick JS, Taft RJ, Faulkner GJ: A global view of genomic informationmoving beyond the gene and the master regulator. Trends Genet 2010, 26:21-28.

14. Peterlin BM, Brogie JE, Price DH: 7SK snRNA: a noncoding RNA that plays a major role in regulating eukaryotic transcription. Wiley Interdiscip Rev RNA 2012, 3:92-103.

15. Espinoza CA, Allen TA, Hieb AR, Kugel JF, Goodrich JA: B2 RNA binds directly to RNA polymerase II to repress transcript synthesis. Nat Struct Mol Biol 2004, 11:822-829.

16. Espinoza CA, Goodrich JA, Kugel JF: Characterization of the structure, function, and mechanism of B2 RNA, an ncRNA repressor of RNA polymerase II transcription. RNA 2007, 13:583-596.

17. Yakovchuk P, Goodrich JA, Kugel JF: B2 RNA represses TFIIH phosphorylation of RNA polymerase II. Transcription 2011, 2:45-49.

18. Sleutels F, Zwart R, Barlow DP: The non-coding Air RNA is required for silencing autosomal imprinted genes. Nature 2002, 415:810-813.

19. Mancini-Dinardo D, Steele SJ, Levorse JM, Ingram RS, Tilghman SM: Elongation of the Kcnq1ot1 transcript is required for genomic imprinting of neighboring genes. Genes Dev 2006, 20:1268-1282.

20. Williamson CM, Ball ST, Dawson C, Mehta S, Beechey CV, Fray M, Teboul L, Dear TN, Kelsey G, Peters J: Uncoupling antisense-mediated silencing and DNA methylation in the imprinted Gnas cluster. PLoS Genet 2011, 7:e1001347.

21. Rinn JL, Kertesz M, Wang JK, Squazzo SL, Xu X, Brugmann SA, Goodnough LH, Helms JA, Farnham PJ, Segal E, Chang HY: Functional demarcation of active and silent chromatin domains in human HOX loci by noncoding RNAs. Cell 2007, 129:1311-1323.

22. Ng SY, Johnson R, Stanton LW: Human long non-coding RNAs promote pluripotency and neuronal differentiation by association with chromatin modifiers and transcription factors. EMBO J 2011, 31:522-533.

23. Guttman M, Rinn JL: Modular regulatory principles of large non-coding RNAs. Nature 2012, 482:339-346.

24. Wutz A: Gene silencing in X-chromosome inactivation: advances in understanding facultative heterochromatin formation. Nat Rev Genet 2011, 12:542-553.

25. Ørom UA, Derrien T, Beringer M, Gumireddy $K$, Gardini A, Bussotti G, Lai F, Zytnicki M, Notredame C, Huang Q, Guigo R, Shiekhattar R: Long noncoding RNAs with enhancer-like function in human cells. Cell 2010, 143:46-58.

26. Wang KC, Yang YW, Liu B, Sanyal A, Corces-Zimmerman R, Chen Y, Lajoie BR, Protacio A, Flynn RA, Gupta RA, Wysocka J, Lei M, Dekker J, Helms JA, Chang HY: A long noncoding RNA maintains active chromatin to coordinate homeotic gene expression. Nature 2011, 472:120-124.

27. Magistri M, Faghihi MA, St Laurent G 3rd, Wahlestedt C: Regulation of chromatin structure by long noncoding RNAs: focus on natural antisense transcripts. Trends Genet 2012, 28:389-396.

28. Heo JB, Sung S: Vernalization-mediated epigenetic silencing by a long intronic noncoding RNA. Science 2011, 331:76-79.

29. Shearwin KE, Callen BP, Egan JB: Transcriptional interference-a crash course. Trends Genet 2005, 21:339-345. 
30. Palmer AC, Egan JB, Shearwin KE: Transcriptional interference by RNA polymerase pausing and dislodgement of transcription factors. Transcription 2011, 2:9-14.

31. Bird AJ, Gordon M, Eide DJ, Winge DR: Repression of ADH1 and ADH3 during zinc deficiency by Zap1-induced intergenic RNA transcripts. EMBO J 2006, 25:5726-5734.

32. Bumgarner SL, Dowell RD, Grisafi P, Gifford DK, Fink GR: Toggle involving cis-interfering noncoding RNAs controls variegated gene expression in yeast. Proc Natl Acad Sci U S A 2009, 106:18321-18326.

33. Petruk S, Sedkov Y, Riley KM, Hodgson J, Schweisguth F, Hirose S, Jaynes JB, Brock HW, Mazo A: Transcription of bxd noncoding RNAs promoted by trithorax represses Ubx in cis by transcriptional interference. Cell 2006, 127:1209-1221.

34. Gummalla M, Maeda RK, Castro Alvarez JJ, Gyurkovics H, Singari S, Edwards $\mathrm{KA}$, Karch F, Bender W: abd-A regulation by the iab-8 noncoding RNA. PLoS Genet 2012, 8:e1002720.

35. Latos PA, Pauler FM, Koerner MV, Senergin HB, Hudson QJ, Stocsits RR, Allhoff W, Stricker SH, Klement RM, Warczok KE, Aumayr K, Pasierbek P, Barlow DP: Airn transcriptional overlap, but not its IncRNA products, induces imprinted Igf2r silencing. Science 2012, 338:1469-1472.

36. Maclsaac JL, Bogutz AB, Morrissy AS, Lefebvre L: Tissue-specific alternative polyadenylation at the imprinted gene Mest regulates allelic usage at Copg2. Nucleic Acids Res 2012, 40:1523-1535.

37. Wood AJ, Schulz R, Woodfine K, Koltowska K, Beechey CV, Peters J, Bourc'his $D$, Oakey RJ: Regulation of alternative polyadenylation by genomic imprinting. Genes Dev 2008, 22:1141-1146.

38. Hobson DJ, Wei W, Steinmetz LM, Svejstrup JQ: RNA polymerase II collision interrupts convergent transcription. Mol Cell 2012, 48:365-374.

39. Kornberg RD, Lorch Y: Twenty-five years of the nucleosome, fundamental particle of the eukaryote chromosome. Cell 1999, 98:285-294.

40. Li B, Carey M, Workman JL: The role of chromatin during transcription. Cell 2007, 128:707-719.

41. Weiner A, Hughes A, Yassour M, Rando OJ, Friedman N: High-resolution nucleosome mapping reveals transcription-dependent promoter packaging. Genome Res 2010, 20:90-100.

42. Hughes AL, Jin Y, Rando OJ, Struhl K: A functional evolutionary approach to identify determinants of nucleosome positioning: a unifying model for establishing the genome-wide pattern. Mol Cell 2012, 48:5-15.

43. Valouev A, Johnson SM, Boyd SD, Smith CL, Fire AZ, Sidow A: Determinants of nucleosome organization in primary human cells. Nature 2011 474:516-520.

44. Segal E, Widom J: What controls nucleosome positions? Trends Genet 2009, 25:335-343.

45. Radman-Livaja M, Rando OJ: Nucleosome positioning: how is it established, and why does it matter? Dev Biol 2010, 339:258-266.

46. Martens JA, Laprade L, Winston F: Intergenic transcription is required to repress the Saccharomyces cerevisiae SER3 gene. Nature 2004, 429:571-574.

47. Belotserkovskaya R, Oh S, Bondarenko VA, Orphanides G, Studitsky VM, Reinberg D: FACT facilitates transcription-dependent nucleosome alteration. Science 2003, 301:1090-1093.

48. Reinberg D, Sims RJ 3rd: de FACTo nucleosome dynamics. J Biol Chem 2006, 281:23297-23301.

49. Nourani A, Robert F, Winston F: Evidence that Spt2/Sin1, an HMG-like factor, plays roles in transcription elongation, chromatin structure, and genome stability in Saccharomyces cerevisiae. Mol Cell Biol 2006, 26:1496-1509.

50. Hainer SJ, Pruneski JA, Mitchell RD, Monteverde RM, Martens JA: Intergenic transcription causes repression by directing nucleosome assembly. Genes Dev 2011, 25:29-40.

51. Thebault P, Boutin G, Bhat W, Rufiange A, Martens J, Nourani A: Transcription regulation by the noncoding RNA SRG1 requires Spt2dependent chromatin deposition in the wake of RNA polymerase II. Mol Cell Biol 2011, 31:1288-1300.

52. Kaplan CD, Laprade L, Winston F: Transcription elongation factors repress transcription initiation from cryptic sites. Science 2003, 301:1096-1099.

53. Cheung V, Chua G, Batada NN, Landry CR, Michnick SW, Hughes TR, Winston F: Chromatin- and transcription-related factors repress transcription from within coding regions throughout the Saccharomyces cerevisiae genome. PLoS Biol 2008, 6:e277.
54. Gallastegui E, Millan-Zambrano G, Terme JM, Chavez S, Jordan A: Chromatin reassembly factors are involved in transcriptional interference promoting HIV latency. J Virol 2011, 85:3187-3202.

55. Bannister AJ, Kouzarides T: Regulation of chromatin by histone modifications. Cell Res 2011, 21:381-395.

56. Brookes E, Pombo A: Modifications of RNA polymerase II are pivotal in regulating gene expression states. EMBO Rep 2009, 10:1213-1219.

57. Ehrensberger AH, Svejstrup JQ: Reprogramming chromatin. Crit Rev Biochem Mol Biol 2012, 47:464-482.

58. $\mathrm{Ng} \mathrm{HH}$, Robert F, Young RA, Struhl K: Targeted recruitment of Set1 histone methylase by elongating Pol II provides a localized mark and memory of recent transcriptional activity. Mol Cell 2003, 11:709-719.

59. Krogan NJ, Kim M, Tong A, Golshani A, Cagney G, Canadien V, Richards DP, Beattie BK, Emili A, Boone C, Shilatifard A, Buratowski S, Greenblatt J: Methylation of histone $\mathrm{H} 3$ by Set2 in Saccharomyces cerevisiae is linked to transcriptional elongation by RNA polymerase II. Mol Cell Biol 2003, 23:4207-4218

60. Schneider R, Bannister AJ, Myers FA, Thorne AW, Crane-Robinson C, Kouzarides T: Histone $\mathrm{H} 3$ lysine 4 methylation patterns in higher eukaryotic genes. Nat Cell Biol 2004, 6:73-77.

61. Carrozza MJ, Li B, Florens L, Suganuma T, Swanson SK, Lee KK, Shia WJ, Anderson S, Yates J, Washburn MP, Workman JL: Histone H3 methylation by Set2 directs deacetylation of coding regions by Rpd3S to suppress spurious intragenic transcription. Cell 2005, 123:581-592.

62. Kim T, Buratowski S: Dimethylation of H3K4 by Set1 recruits the Set3 histone deacetylase complex to 5 ' transcribed regions. Cell 2009, 137:259-272.

63. Keogh MC, Kurdistani SK, Morris SA, Ahn SH, Podolny V, Collins SR, Schuldiner M, Chin K, Punna T, Thompson NJ, Boone C, Emili A, Weissman JS, Hughes TR, Strahl BD, Grunstein M, Greenblatt JF, Buratowski S, Krogan $\mathrm{NJ}$ : Cotranscriptional set2 methylation of histone $\mathrm{H} 3$ lysine 36 recruits a repressive Rpd3 complex. Cell 2005, 123:593-605.

64. van Werven FJ, Neuert G, Hendrick N, Lardenois A, Buratowski S, van Oudenaarden A, Primig M, Amon A: Transcription of two long noncoding RNAs mediates mating-type control of gametogenesis in budding yeast. Cell 2012, 150:1170-1181

65. Houseley J, Rubbi L, Grunstein M, Tollervey D, Vogelauer M: A ncRNA modulates histone modification and mRNA induction in the yeast GAL gene cluster. Mol Cell 2008, 32:685-695.

66. Kim T, Xu Z, Clauder-Munster S, Steinmetz LM, Buratowski S: Set3 HDAC mediates effects of overlapping noncoding transcription on gene induction kinetics. Cell 2012, 150:1158-1169.

67. Jones PA: Functions of DNA methylation: islands, start sites, gene bodies and beyond. Nat Rev Genet 2012, 13:484-492.

68. Deaton AM, Bird A: CpG islands and the regulation of transcription. Genes Dev 2011, 25:1010-1022.

69. Ooi SK, O'Donnell AH, Bestor TH: Mammalian cytosine methylation at a glance. J Cell Sci 2009, 122:2787-2791.

70. Ooi SK, Qiu C, Bernstein E, Li K, Jia D, Yang Z, Erdjument-Bromage H, Tempst $P$, Lin SP, Allis CD, Cheng X, Bestor TH: DNMT3L connects unmethylated lysine 4 of histone $\mathrm{H} 3$ to de novo methylation of DNA. Nature 2007, 448:714-717.

71. Tufarelli C, Stanley JA, Garrick D, Sharpe JA, Ayyub H, Wood WG, Higgs DR: Transcription of antisense RNA leading to gene silencing and methylation as a novel cause of human genetic disease. Nat Genet 2003, 34:157-165.

72. Ligtenberg MJ, Kuiper RP, Chan TL, Goossens M, Hebeda KM, Voorendt M, Lee TY, Bodmer D, Hoenselaar E, Hendriks-Cornelissen SJ, Tsui WY, Kong CK Brunner HG, van Kessel AG, Yuen ST, van Krieken JH, Leung SY, Hoogerbrugge N: Heritable somatic methylation and inactivation of MSH2 in families with Lynch syndrome due to deletion of the 3' exons of TACSTD1. Nat Genet 2009, 41:112-117.

73. Santoro F, Barlow DP: Developmental control of imprinted expression by macro non-coding RNAs. Semin Cell Dev Biol 2011, 22:328-335.

74. Santoro F, Mayer D, Klement RM, Warczok KE, Stukalov A, Barlow DP, Pauler FM: Imprinted Igf2r silencing depends on continuous Airn IncRNA expression and is not restricted to a developmental window. Development 2013, 140:1184-1195.

75. Pauler FM, Barlow DP, Hudson QJ: Mechanisms of long range silencing by imprinted macro non-coding RNAs. Curr Opin Genet Dev 2012, 22:283-289.

76. Pauler FM, Koerner MV, Barlow DP: Silencing by imprinted noncoding RNAs: is transcription the answer? Trends Genet 2007, 23:284-292. 
77. Barlow DP: Genomic imprinting: a mammalian epigenetic discovery model. Annu Rev Genet 2011, 45:379-403.

78. Koerner MV, Pauler FM, Huang R, Barlow DP: The function of non-coding RNAs in genomic imprinting. Development 2009, 136:1771-1783.

79. Wang ZQ, Fung MR, Barlow DP, Wagner EF: Regulation of embryonic growth and lysosomal targeting by the imprinted lgf2/Mpr gene. Nature 1994, 372:464-467.

80. Pauler FM, Stricker SH, Warczok KE, Barlow DP: Long-range DNase I hypersensitivity mapping reveals the imprinted Igf $2 \mathrm{r}$ and Air promoters share cis-regulatory elements. Genome Res 2005, 15:1379-1387.

81. Stoger R, Kubicka P, Liu CG, Kafri T, Razin A, Cedar H, Barlow DP: Maternalspecific methylation of the imprinted mouse lgf2r locus identifies the expressed locus as carrying the imprinting signal. Cell 1993, 73:61-71.

82. Racanelli AC, Turner FB, Xie LY, Taylor SM, Moran RG: A mouse gene that coordinates epigenetic controls and transcriptional interference to achieve tissue-specific expression. Mol Cell Biol 2008, 28:836-848.

83. Palmer AC, Ahlgren-Berg A, Egan JB, Dodd IB, Shearwin KE: Potent transcriptional interference by pausing of RNA polymerases over a downstream promoter. Mol Cell 2009, 34:545-555.

84. Adelman K, Lis JT: Promoter-proximal pausing of RNA polymerase II: emerging roles in metazoans. Nat Rev Genet 2012, 13:720-731.

85. Levine M: Paused RNA polymerase II as a developmental checkpoint. Cell 2011, 145:502-511.

86. Nagano T, Mitchell JA, Sanz LA, Pauler FM, Ferguson-Smith AC, Feil R, Fraser $P$ : The Air noncoding RNA epigenetically silences transcription by targeting G9a to chromatin. Science 2008, 322:1717-1720.

87. Mager J, Montgomery ND, de Villena FP, Magnuson T: Genome imprinting regulated by the mouse Polycomb group protein Eed. Nat Genet 2003 33:502-507.

88. Terranova R, Yokobayashi S, Stadler MB, Otte AP, van Lohuizen M, Orkin SH, Peters AH: Polycomb group proteins Ezh2 and Rnf2 direct genomic contraction and imprinted repression in early mouse embryos. Dev Cell 2008, 15:668-679.

89. Korostowski L, Sedlak N, Engel N: The Kenq1 ot1 long non-coding RNA affects chromatin conformation and expression of Kcnq1, but does not regulate its imprinting in the developing heart. PLoS Genet 2012, 8:e1002956.

90. Visel A, Rubin EM, Pennacchio LA: Genomic views of distant-acting enhancers. Nature 2009, 461:199-205.

91. Ong CT, Corces VG: Enhancers: emerging roles in cell fate specification. EMBO Rep 2012, 13:423-430.

92. Kim TK, Hemberg M, Gray JM, Costa AM, Bear DM, Wu J, Harmin DA, Laptewicz M, Barbara-Haley K, Kuersten S, Markenscoff-Papadimitriou E, Kuhl D, Bito H, Worley PF, Kreiman G, Greenberg ME: Widespread transcription at neuronal activity-regulated enhancers. Nature 2010, 465:182-187.

93. Schatz DG, Swanson PC: V(D)J recombination: mechanisms of initiation. Annu Rev Genet 2011, 45:167-202.

94. Bolland DJ, Wood AL, Afshar R, Featherstone K, Oltz EM, Corcoran AE: Antisense intergenic transcription precedes Igh D-to-J recombination and is controlled by the intronic enhancer Emu. Mol Cell Biol 2007 27:5523-5533

95. Giallourakis CC, Franklin A, Guo C, Cheng HL, Yoon HS, Gallagher M, Perlot T, Andzelm M, Murphy AJ, Macdonald LE, Yancopoulos GD, Alt FW: Elements between the IgH variable $(\mathrm{V})$ and diversity (D) clusters influence antisense transcription and lineage-specific V(D)J recombination. Proc Natl Acad Sci U S A 2010, 107:22207-22212.

96. Abarrategui I, Krangel MS: Noncoding transcription controls downstream promoters to regulate T-cell receptor alpha recombination. EMBO J 2007, 26:4380-4390.

97. Ashe HL, Monks J, Wijgerde M, Fraser P, Proudfoot NJ: Intergenic transcription and transinduction of the human beta-globin locus. Genes Dev 1997, 11:2494-2509.

98. Gribnau J, Diderich K, Pruzina S, Calzolari R, Fraser P: Intergenic transcription and developmental remodeling of chromatin subdomains in the human beta-globin locus. Mol Cell 2000, 5:377-386.

99. Cumberledge S, Zaratzian A, Sakonju S: Characterization of two RNAs transcribed from the cis-regulatory region of the abd-A domain within the Drosophila bithorax complex. Proc Natl Acad Sci U S A 1990, 87:3259-3263.

100. Beisel C, Paro R: Silencing chromatin: comparing modes and mechanisms. Nat Rev Genet 2011, 12:123-135.

101. Schmitt S, Prestel M, Paro R: Intergenic transcription through a polycomb group response element counteracts silencing. Genes Dev 2005, 19:697-708
102. Sessa L, Breiling A, Lavorgna G, Silvestri L, Casari G, Orlando V: Noncoding RNA synthesis and loss of Polycomb group repression accompanies the colinear activation of the human HOXA cluster. RNA 2007, 13:223-239.

103. Kanhere A, Viiri K, Araújo CC, Rasaiyaah J, Bouwman RD, Whyte WA, Pereira CF, Brookes E, Walker K, Bell GW, Pombo A, Fisher AG, Young RA, Jenner RG: Short RNAs are transcribed from repressed polycomb target genes and interact with polycomb repressive complex-2. Mol Cell 2010, 38:675-688.

104. Hekimoglu-Balkan B, Aszodi A, Heinen R, Jaritz M, Ringrose L: Intergenic Polycomb target sites are dynamically marked by non-coding transcription during lineage commitment. RNA Biol, 9:314-325.

105. Uhler JP, Hertel C, Svejstrup JQ: A role for noncoding transcription in activation of the yeast PHO5 gene. Proc Natl Acad Sci U S A 2007, 104:8011-8016.

106. Neil H, Malabat C, d'Aubenton-Carafa Y, Xu Z, Steinmetz LM, Jacquier A: Widespread bidirectional promoters are the major source of cryptic transcripts in yeast. Nature 2009, 457:1038-1042

107. Seila AC, Calabrese JM, Levine SS, Yeo GW, Rahl PB, Flynn RA, Young RA, Sharp PA: Divergent transcription from active promoters. Science 2008 322:1849-1851.

108. Brosius J: Waste not, want not-transcript excess in multicellular eukaryotes. Trends Genet 2005, 21:287-288.

109. Kowalczyk MS, Higgs DR, Gingeras TR: Molecular biology: RNA discrimination. Nature 2012, 482:310-311.

110. Wang GZ, Lercher MJ, Hurst LD: Transcriptional coupling of neighboring genes and gene expression noise: evidence that gene orientation and noncoding transcripts are modulators of noise. Genome Biol Evol 2011. 3:320-331.

111. Ulitsky I, Shkumatava A, Jan $\mathrm{CH}$, Sive $\mathrm{H}$, Bartel DP: Conserved function of lincRNAs in vertebrate embryonic development despite rapid sequence evolution. Cell 2011, 147:1537-1550.

112. Zeng Y, Cullen BR: RNA interference in human cells is restricted to the cytoplasm. RNA 2002, 8:855-860.

113. Ohrt T, Muetze J, Svoboda P, Schwille P: Intracellular localization and routing of miRNA and RNAi pathway components. Curr Top Med Chem 2012, 12:79-88.

114. Ideue T, Hino K, Kitao S, Yokoi T, Hirose T: Efficient oligonucleotidemediated degradation of nuclear noncoding RNAs in mammalian cultured cells. RNA 2009, 15:1578-1587.

115. Tse MT: Antisense therapeutics: Nuclear RNA more susceptible to knockdown. Nat Rev Drug Discov 2012, 11:674.

116. Zhang B, Arun G, Mao YS, Lazar Z, Hung G, Bhattacharjee G, Xiao X, Booth CJ, Wu J, Zhang C, Spector DL: The IncRNA Malat1 is dispensable for mouse development but its transcription plays a cis-regulatory role in the adult. Cell Rep 2012, 2:111-123.

117. Nakagawa S, Naganuma T, Shioi G, Hirose T: Paraspeckles are subpopulation-specific nuclear bodies that are not essential in mice. J Cell Biol, 193:31-39.

118. Eißmann M, Gutschner T, Hämmerle M, Günther S, Caudron-Herger M, Groß M, Schirmacher P, Rippe K, Braun T, Zörnig M, Diederichs S: Loss of the abundant nuclear non-coding RNA MALAT1 is compatible with life and development. RNA Biol 2012, 9:1076-1087.

119. Nakagawa S, Ip JY, Shioi G, Tripathi V, Zong X, Hirose T, Prasanth KV: Malat1 is not an essential component of nuclear speckles in mice. RNA 2012, 18:1487-1499.

120. Schorderet $P$, Duboule D: Structural and functional differences in the long non-coding RNA hotair in mouse and human. PLoS Genet 2011, 7:e1002071.

121. Guenzl PM, Barlow DP: Macro IncRNAs: A new layer of cis-regulatory information in the mammalian genome. RNA Biol 2012, 9:731-741.

122. Carette JE, Guimaraes CP, Wuethrich I, Blomen VA, Varadarajan M, Sun C, Bell G, Yuan B, Muellner MK, Nijman SM, Ploegh HL, Brummelkamp TR: Global gene disruption in human cells to assign genes to phenotypes by deep sequencing. Nat Biotechnol 2011, 29:542-546.

123. Wirt SE, Porteus MH: Development of nuclease-mediated site-specific genome modification. Curr Opin Immunol 2012, 24:609-616.

124. Mali P, Yang L, Esvelt KM, Aach J, Guell M, Dicarlo JE, Norville JE, Church GM: RNA-Guided Human Genome Engineering via Cas9. Science 2013, 339:823-826.

125. Latos PA, Stricker SH, Steenpass L, Pauler FM, Huang R, Senergin BH, Regha K, Koerner MV, Warczok KE, Unger C, Barlow DP: An in vitro ES cell imprinting model shows that imprinted expression of the lgf $2 r$ gene arises from an allele-specific expression bias. Development 2009, 136:437-448. 
126. Kohama C, Kato H, Numata K, Hirose M, Takemasa T, Ogura A, Kiyosawa H: ES cell differentiation system recapitulates the establishment of imprinted gene expression in a cell-type-specific manner. Hum Mol Genet 2012, 21:1391-1401.

127. Rosenbloom KR, Sloan CA, Malladi VS, Dreszer TR, Learned K, Kirkup VM, Wong MC, Maddren M, Fang R, Heitner SG, Lee BT, Barber GP, Harte RA, Diekhans M, Long JC, Wilder SP, Zweig AS, Karolchik D, Kuhn RM, Haussler D, Kent WJ: ENCODE Data in the UCSC Genome Browser: year 5 update. Nucleic Acids Res 2013, 41:D56-63.

128. Loven J, Orlando DA, Sigova AA, Lin CY, Rahl PB, Burge CB, Levens DL, Lee TI, Young RA: Revisiting global gene expression analysis. Cell 2012, 151:476-482.

129. Clark MB, Mattick JS: Long noncoding RNAs in cell biology. Semin Cell Dev Biol 2011, 22:366-376.

doi:10.1186/1741-7007-11-59

Cite this article as: Kornienko AE et al: Gene regulation by the act of

long non-coding RNA transcription. BMC Biology 2013 11:59. 